\title{
Regional Government Public Policy Implementation in Tourism Development
}

\author{
Ibnu Kanaha, Arif Darmawan, Rachmawati Novaria \\ Doctoral Administration Study Program, 17 Agustus 1945 University of Surabaya, East Java, Indonesia
}

Email address:

ibnukanaha@gmail.com (I. Kanaha)

\section{To cite this article:}

Ibnu Kanaha, Arif Darmawan, Rachmawati Novaria. Regional Government Public Policy Implementation in Tourism Development. Science, Technology \& Public Policy. Vol. 4, No. 2, 2020, pp. 76-84. doi: 10.11648/j.stpp.20200402.15

Received: August 17, 2020; Accepted: September 5, 2020; Published: September 19, 2020

\begin{abstract}
This study aims to analyze the description and explanation of the Implementation of Policy No. 09/2014 on the Regional Tourism Development Master Plan (RIPPDA) in tourism development. In addition, it analyzes the strategy of supporting factors and inhibiting factors for policy implementation. The research method is qualitative description, while the determination of the research location in the Morotai Island Regency area is carried out purposively, with sources or informants including the Head of the Tourism Office, the Regent, the Regional Secretary, the Regional People's Consultative Council (DPRD), local tourism object actors in the in the environment of Morotai Island Regency as an authorized official or related to the problem. Methods of data collection using observation, in-depth interviews (depth interview), documentation. Meanwhile, the data analysis technique in this study uses an interactive perspective method, and the validity of the data can be tested, following the triangulation method, namely, data reduction, data display, data verification, simultaneously with the implementation of checking techniques for a number of certain criteria, and also some aspects used in implementation. policy 1) Aspect of policy implementation process, 2) Aspect of impact of policy implementation, 3) Aspect of policy strategy, factors affecting policy implementation. The results of the research on Policy Implementation show that it has not achieved its objectives optimally. This needs to be seen from several problems: 1) Standard targets, policy objectives have not been given an understanding of the interests of the policy, this is complementary so that they do not know; 2) Human Resources for Implementers; 3) Characteristics of the fragmentation implementing organization (SOP); 4) The weakness of communication and coordination; 5) The attitude of the policy makers "from the top down" (top bottomer) in choosing the implementation of policies that are self-interested is not based on RIPPDA; 6) The lack of support from the external social, economic and political environment. Suggestions for RIPPDA research need to be revised by the Regional Government of Morotai Island Regency and the Tourism Office in synergy, synchronization, coordination with good work networks, support from external parties so that the Regional Tourism Development Master Plan policy can achieve its goals, tourism can develop.
\end{abstract}

Keywords: Policy Implementation, Local Government, Tourism Development

\section{Introduction}

Law Number 32 of 2004, Law Number 23 of 2014 gives authority to local governments to manage their territories, provides great enthusiasm, and brings the implication of being increasingly responsible for exploring and developing all potential resources owned by the region, so the government as the organizer must be based on with the principles of benefit, joint effort, fairness and equality in the balance in the tourism development program as one sector of the tourism economy industry. Implementation of Law Number. 10 of 2009 concerning tourism, article 23 point c states, maintains, develops and preserves national assets that become tourist attractions and potential assets that have not been explored. The Central Government and Regional Governments have the authority to realize tourism as an industry to push the APBN and APBD with the policies of the Central Government and Regional Governments. Therefore, the tourism sector is a priority sector in development in Indonesia which currently has very high prospects to be developed specifically for tourism.

To achieve the goal, the implementation of the right policy is of course the right tools provided, as well as achieving the goals that have been previously set. According to Riant 
Nugroho (2004), there are three indicators to measure the effectiveness of policy implementation. First, whether the policies themselves are appropriate, it means that these policies are judged as far as the existing policies contain matters that solve the problems to be solved; Second, whether the policy has been formulated in accordance with the character of the problem to be solved; Third, whether the policy is made by an authorized institution in accordance with the character of the policy; Fourth, it is the place where political support, strategic support and technical support need to be supported. That is, the policy is an institution that becomes the implementation, the government, cooperates between the government and private companies, or the implementation of the policy is privatized. The third right is right on target, is the target invested in accordance with what was planned or is it not in conflict with other policy infestations; Policy implementation is the most crucial stage in the public policy process.

Thus, policy implementation should have the support of the bureaucracy who has the capacity to determine the implementation of existing policies with financial support. However, under current objective conditions, it is believed that the government policy of the Tourism Development Master Plan (RIPPDA) is not yet one of the strategic requirements to guide tourism development in Morotai Island Regency. This is, the temporary tourism development pattern is solely guided by existing policies, but is carried out based on the needs of the Morotai Island Regency Tourism Office, even these policies are not relevant to the current conditions which are not objective. Due to the low level of understanding which has an impact on internal bureaucratic participation, coordination and cooperation have not been well developed between stakeholders and stakeholders and human resource support for implementing existing policies is very limited.

To measure the success of policy or program implementation can be detected, it is necessary to face several problems regarding the Implementation of Policy No. 09/2014 concerning the Regional Tourism Development Master Plan (RIPPDA) in Morotai Island Regency has not achieved its objectives optimally due to a lack of socialization, education, and work plan coordination. The success of policy implementation needs to pay attention to the problems. According to Swarbrooke (2003: 88) actors who fight optimally in each sub-sector will determine the success of tourism, as well as the functions played by the actual actors so that they become an important source of inspiration in policy formulation and implementation [12]. Local governments are actors who play a very important role in dealing with problems with tourism development, making strategic efforts by making policies involving local communities who have human resources for tourism objects, so they need to be encouraged to make optimal use of them, in the form of a Regional Tourism Development Master Plan that can be expected encourage the implementation of development in the tourism industry sector in order to make a positive contribution to the region with tourism development.
Based on the description above, this research can be supported by supporting data that comes from various references as well as documents and facts in the field of information through informants obtained in the field, thus it can be said that this research is original because it is different from various studies, the focus of previous research, and the two aspects mentioned above need serious attention.

\section{Materials and Methods}

\subsection{The Implementation of Public Policy}

Policy implementation is an attempt to determine the level of success in policy implementation and the variables that influence it. In a broad sense, policy implementation is seen as a means of public administration where actors, organizations, procedures, techniques and resources are organized together to carry out policies to achieve the impact or goals used by Budi Winarno (2017: 133) [2] while Hinggis in Pasolong (2011: 57) defines implementation as a summary of various activities in which human resources use other resources to achieve strategic goals [8]. According to Van Meter and Van Horn in Nawawi (2009: 131) defining policy implementation, is an action taken either by individuals or officials or government or private groups directed towards achieving the goals outlined in policy decisions [7].

However, currently, the tourism development in Morotai Island Regency has not been able to be carried out according to the expectations set forth in Policy No. 09/2014 The Master Plan for Regional Tourism Development (RIPKDA) is wanted beforehand, besides that the region still has many limitations in various aspects related to supporting facilities for regional tourism facilities, infrastructure, accessibility, and other supporting facilities [11]. Strategies that can be carried out are government commitments regarding the focus of regional tourism development, launching the concept of City branding are strategies carried out by a country or region making Positioning in their target market such as Positioning a product or service so that the country or region becomes a distinctive tourism icon, enhances partnerships and relations between institutions in tourism management, regulatory support and human resource development.

This strategy can be developed in order to increase local revenue from the tourism sector in Morotai Island Regency. By implementing various policies and development efforts as a form of commitment of the regional government in achieving regional development targets.

\subsection{Policy Formulation on Tourism}

The formulation of policies is a continuation of the policy process, in essence the formulation of public issues, which is aimed at implementing interventions to improve tourism development. Keynes (1932) in Riant Nugroho (2017: 546) The government is actually starting to be interventive in overcoming problems through policies to maintain the continuity of life together, especially tourism development. Keynes, who became the focus of intervention which became 
the focus of policy, was to lead to actions that could be taken in areas that could indeed be intervened, one of which was the intervention of community involvement and policy interest groups in policy formulation, regarding the formulation of problems, tourism problems and problems [9]. public, communicated to policy interests as well as policy experts to recommend.

According to Keynes, the government must make longterm planning stages, the long-term plan is benefited by its successors, but in practice it must be the government that it leads to focus on the next five years for leadership and management. The second intervention of the government is the ability of human resources, including good public policy resources, so that it cannot be implemented properly, it is impossible to build a district and enter the hi-tech industry, we will compete with regions such as Java and Bali, or other countries. Neighbors, there will be a social gap between local approaches.

\subsection{Tourism Development and Destinations}

the provisions of Law number 10 of 2009 concerning tourism, in principle, all tourism implementation policies in Indonesia must be based on the principles and principles contained in the tourism law with all applicable regulations, the principles of the law mentioned above, are fundamental to the implementation of tourism which has directed by tourism objectives are; First, is to increase economic growth; Second, improve community welfare; Third, eradicating poverty; Fourth, overcoming unemployment; fifth, conserving nature and the environment and natural resources; Sixth, promoting culture; And finally, cultivating the taste of water cloves; Eighth, strengthen the identity and unity of the nation and; Ninth, strengthen friendship between nations.

The principle of implementing tourism is in essence there is coordination and synchronization between programs and existing stakeholders, program coordination and synchronization of course involves active participation which is integrated synergy and mutually reinforcing) between the government and private parties, and the communities they are concerned with, so that the implementation of tourism development can be sustainable and easily recognized by the various characteristics of its administration. Based on the principle of obedience (Bambang Sunaryo, 2013: 80) [3].

\subsection{Study of Policy Implementation Aspects}

Studies on aspects of policy implementation, especially in relation to the problem of policy implementation in tourism development can be found in research at the local level which can be found in one of Agustina Pallewa's previous studies, 2017, Tourism Development Policy in Agustina's work which has explained that policy implementation in tourism development has several specific reasons for developing policy implementation capabilities [1].

This was revealed by Agustina Pallewa (2017) and the following research results were as follows; (a) The implementation of policies as a whole has not run optimally, due to a lack of socialization and education related to communication of tourism policy plans so that the coordination and synchronization of policies are not understood by stakeholders so that the program does not run as targeted; (b) inadequate human resources, commitment, loyalty and professionalism of tourism officials and other agencies need to be improved so that they are able to implement tourism policies as a development driver other than budget resources; (c) the disposition or attitude of implementing policies adopted in the work program based on the preparation of the real program; (d) the bureaucratic structure is not well coordinated in carrying out its duties to support tourism development [1].

This study is of relevance to the implementation of local government policies regarding the Regional Tourism Development Master Plan (RIPPD) of Morotai Island Regency clearly that the implementation of policies in tourism development The government lacks communication through socialization and education related to tourism policy plans, so coordination and synchronization of tourism development policies is lacking understood by other stakeholders [11]. So that the impact on the program is not running as targeted. Tourism Development Master Plan Policy No. 09/2014 which has been determined will then be implemented by the Regional Government (local bureaucracy) under the control of the Head of Region and the Regional Secretary.

In this case, a consistent, responsive and accountable performance of various Regional Apparatus institutions is needed, not only that but marked by creativity, skills, and professional potential to make changes in managing the tourism industry which brings the greatest benefits for the interests of the region and society.. The implementation of policies that are creativity, skills, competent and professional in this case can be realized if the values of efficiency, adequacy, and accountability of the manager are upheld.

\subsection{Framework of Thingking}

The government has the authority to make policies in this case, the policy of Nomo, 09/2014 concerning the Regional Tourism Development Master Plan (RIPPDA). Through Law Number 23 of 2014 concerning Regional Government mandates the special authority of regional institutions known as the term of regional autonomy. This authority provides flexibility for district / city governments to take care of their own household affairs, with the aim of improving the welfare of the local community, according to their capabilities and potentials (Rasyid, 2002: 9) [10].

With the development of the concept of regional autonomy in the implementation of regional development, the regional government has the authority to manage, utilize, and manage every asset and resource that the region has potential, especially the potential for the tourism industry to be empowered so that it can make a real contribution to regional development. The regional government is directed to be able to determine sectors that can encourage tourism to increase development in Morotai Island Regency. 
The tourism sector is one of the priority sectors in regional development at this time because it has enormous prospects in tourism development. Therefore, based on the provisions of Law number 10 of 2009 concerning Tourism, it is supported by a Tourism Development Master Plan (RIPPDA) which subsequently becomes a guideline for each region in formulating and formulating tourism development policies in accordance with the characteristics and potential of the region itself, this is not it is only used as a form of administrative obedience of regional institutions for the implementation of the bureaucracy but is a form of understanding the needs set forth in a policy that can be implemented with the responsibility of all stakeholders.

According to Van Meter and Van Horn in Nawawi (2009: 131) defining policy implementation, is an action taken either by individuals or officials or government or private groups directed to achieve the goals outlined in policy decisions [7]. Implementation is a process of activities / actions both carried out by individuals, leaders or government and private groups who are in charge of and to achieve goals that have been decided or established by policies. The definition above is coupled with public policy, so the word implementation of public policy can be defined as the activity of completing or implementing a public policy that has been determined or approved by the use of means (tools) to achieve policy objectives.

However, at this time, to measure the level of success in Morotai Island Regency, tourism development is said to have not been able to be carried out as expected, and there are also many limitations in various aspects related to tourism support facilities, such as infrastructure, access, above. This means that the regional government has the authority to handle problems through policies and tourism development efforts carried out as a form of commitment from the Morotai Island Regency government in achieving the goal of the spirit of the principle of regional autonomy.

\section{Research Methods}

To see, know, and describe the actual situation in detail and actual by looking at the problems and research objectives as previously stated, this research method is a qualitative approach, the essence of this method according to Burhan (2001); (1) Anthologically, epistomology is crical realism, which views social reality as real, according to natural law, but it is impossible if a social reality can be seen correctly by humans (researchers) (2); Methodologically, the experimental approach through observation is not enough to find the truth of the data, but it must use the triarangulation method, which is to use various methods of research data sources and theories. (3); Epistomologically, the relationship between observers or researchers and the object or social reality being studied is not separated [4].

The focus of this research is closely related to the formulation of the problem, because the research problem becomes a reference in determining the focus of research, with the aim of limiting research, it can also develop based on the research problem situation in the field. What is the Process of Implementing Policy Number 09 of 2014 Master Plan for Regional Tourism Development in tourism development based on aspects of efficiency and effectiveness of Morotai Island Regency. What is the Impact of the Implementation of Policy No. 09/2014 on the Master Plan for Tourism Development based on the Adequacy and Responsiveness Aspects of Morotai Island Regency? What are the Supporting Factors and Inhibiting Factors for Policy Implementation in Tourism Development in Morotai Island Regency.

As for making the operational focus of research easier, each aspect that is seen is determined; 1) Process aspects, achieving the stated policy implementation goals; 2) Aspects of the impact of policy implementation; 3) Strategic aspects of supporting factors and obstacles to policy implementation. Apart from the three descriptions of the aspects of the research focus, there are also strategic factors influencing strategy and factors affecting policy implementation. 1. Supporting factors; a) Supporting factors from the internal environment; b) Supporting factors from the external environment; c) internal environment. 2. Inhibiting factor; a) Inhibiting factors from the internal environment; b) The inhibiting factors of the external environment.

Location in Morotai Island Regency, which has something to do with the implementation of policies in tourism development. The research location was determined purposively, for the following reasons: (1). Morotai Island Regency has a strong tourism potential, commencing in the second war between the Japanese and the American allies led by General Douglas Mc Arthur. (2) The Regency of Morotai Island as one of the autonomous regions is quite mature even though it is still a new division area, whose geographic position is very strategic at the edge of the Asia Pacific trade route to become a special economic area (KEK). (3). Morotai Island Regency has a very strategic geography and administration which is the border area for the defense of government administration and the development of state defense in eastern Indonesia. (4). Morotai Island District has empirical facts about the implementation of tourism development policies in successful tourism affairs and can be applied as international tourism, as a driving force for APBD and community welfare.

The sources or informants include: 1). Morotai Island Regency Tourism Office (authorized or related officials) with the issue of Policy Implementation No. 09/2014 Regional Tourism Development Master Plan (RIPPDA). Morotai Island Regency. 2) Morotai Island Regency Government. In this case, the Regent, Regional Secretary as the official in charge of or related to the issue of Policy Implementation No. 09/2014 Regional Tourism Development Master Plan (RIPPDA). Morotai Island Regency. 3) The Regional People's Consultative Council (DPRD) and the secretary of the council, as officials in charge of or related to the issue of Policy Implementation No. 09/2014 Regional Tourism Development Master Plan (RIPPDA). Morotai Island Regency. 4) The community, and local tourism object actors 
in the Morotai island district [11].

Data Collection Methods, Moloeng (2015: 52) argues that in order to collect the data needed in this study, the researchers used basic techniques, namely: Observation, Indepth Interview (in-depth interview), Documentation [6]. Data analysis technique, a method or way to manage data into information easily to understand and also to find problems, the goal is to describe the whole data so that it can be understood and can also make conclusions. In addition to analyzing the research results will be translated and described qualitatively in order to obtain a picture of the situation or event that occurred in the field.

The research data analysis technique uses an interactive perspective method, by continuous to completion, so that the data is saturated, the activities in the analysis are 3 streams, namely: data reduction, data display, data verification, simultaneously: Miles et al. (1994: 12). 1) Data reduction obtained from written notes from the field, namely interview transcripts, documentation and other empirical material, set out in a complete and detailed description or report. 2) Data display / data display is an activity when information collection is organized or organized into a certain concept and certain category by summarizing statements of information that allow conclusions and actions, so that it can help in understanding what happened and to do something, including more detailed analysis. deep or take action based on understanding. 3) Compilation and cross-sectional data relating to facts in the field, transcripts of interviews conducted through electronic sura containing related problems in the field and also additional data that supports the representation of researchers with the reporting model carried out. 4) Withdrawal of conclusions / verification, from the beginning of data collection, a Triangulation analyzer, to check the correctness of certain data by comparing it with data obtained from other sources, is done by matching data or ensuring the correctness of the data from other informants.

\section{Result and Discussion}

\subsection{Explanation Regarding Policy Implementation No. 09/2014 Regional Tourism Development Master Plan}

\subsubsection{Policy Implementation Process}

After understanding in general about the process of implementing the local government policies in Morotai Island Regency, in this section the researchers describe specifically how the policy implementation process in tourism development is currently taking place. The process of implementing policy implementation is related to the affairs of the task of regulating, managing and running programs implemented by local governments with reference to Law Number. 10 of 2009 concerning tourism article 23 point c states, maintaining, developing and preserving National assets which are tourist attractions and untapped potential assets.

In a more precise context, the central and local governments have the authority to realize tourism as an industry to push the APBN and APBD with the policies of the central government and local governments. Therefore, the tourism sector is a priority sector in development in Indonesia which currently has very high prospects to be developed specifically for tourism. The implementation of the Regional Tourism Development Master Plan (RIPPD) policy and the Tourism Law Act in terms of maintaining, developing and preserving the national assets of this study, researchers analyzed and reviewed the success of policy implementation. between the results and the objectives of the policy yields less than optimal results [11].

It can be seen that local government policies are inconsistent and not in favor of tourism development, but because policy analysts, policy makers, and other policy actors have assumptions that often contradict human nature and the possibility of social change through policy action, because policies that can shown the perpetrators in Morotai Island Regency.

\subsubsection{Analysis of the Impact of Policy Implementation}

Analysis of the impact of policy implementation carried out by local governments to achieve goals by analyzing documents regarding the existence of existing policy No. $09 / 2014$, analyzing facts from field observations and analysis of regulatory documents related to policy implementation in tourism development shows that the Morotai Island Regency Government Policy No. 09/2014 The Master Plan for Tourism Development (RIPPDA), which is still in effect today, does not appear to be running on target. First: Policy standards and objectives, the interaction between policy making and implementation of policies (officals) do not understand policy standards and objectives, because policy standards and objectives relate to the attitudes of the implementers [11].

However, the policy standard and program content in the policy have not been given an understanding of the interests of the policy, in this case the policy implementer, so they do not know how the standards and policy objectives are in the effectiveness of policy implementation. Second: Resources, human resources, budget, time not yet available Human Resources (HR) Implementers. Third, the characteristics of the organization implementing standard operating procedures (SOP) and fragmentation. Fragmentation is a condition due to pressures from the bureaucratic environment, including the political environment to the constitution. Characteristics of the bureaucratic structure Standard Operating Procedures (SOP) and the distribution of responsibility for the implementation of policies in tourism development related to Policy No. 09/2014 concerning the Regional Tourism Development Master Plan (RIPPDA) is one (umbrella) but does not refer to the Regional Tourism Development Master Plan. (RIPKDA) Fourth: Lemanya communication and coordination between Local Government (Regent), private companies, DPRD, Tourism Office and related departments, Society; Fifth: The attitude of policy makers is "from the top down" (top bottomer) and the selection of policy implementation those that are self-interested are not based on 
the Regional Tourism Development Master Plan (RIPPDA), so that policy implementers who do not know are not even able to touch the needs, wants, or problems that must be resolved; Sixth: The support for the social, economic and political environment is weak;: There is a physical carrying capacity Social and cultural aspects in tourism development that must be considered and made the main consideration in developing various tourism facilities and activities, including physical, social and cultural carrying capacity in accordance with the limits of local capacities and existing environmental support capacities. Based on the description above, it can be said that this research is different from various studies, the focus of previous research.

\subsection{Strategies and Factors Affecting Policy Implementation}

Strategy and policy direction is a comprehensive planning on how local governments can achieve the goals and objectives of policy implementation effectively and efficiently, because the strategy must be implemented as an important reference in policy implementation planning. The formulation of the strategy is in the form of a statement explaining how the goals and objectives will be achieved, which is then explored by a time horizon with a series of policy directions.

Strategies are steps that contain master programs to realize the vision and mission, a strategy can be connected with the achievement of one goal. In the case that several goals are inherent with one theme, one strategy can be formulated to achieve a combination of these goals. In achieving policy implementation, there are factors affecting policy implementation as follows; The first factor influencing policy implementation: is the standard, and policy objectives, the implementers (officals) understand the standards and policy objectives, because policy standards and objectives are related to the attitudes of the implementers. However, policy standards and program content in policies have not been given understanding or given socialization to policy interests, in this case policy implementers, so they do not know how the policy standards are in the effectiveness of policy implementation.

Second: Resources, human resources, budget are not yet available. Human Resources (HR) Implementers, with a lack of human resources, of course the ability to carry out policies or manage programs that have been programmed will not succeed, at least have special abilities in the field of tourism management such as tourism human resources, ability in terms of policy communication and compliance in policies organizations and individuals regarding existing regulatory policies, and the lack of spokespersons who accompany foreign tourists, such as interpreters for language guides for every tourist from outside of the country what actions should be taken in the implementation of the field, this is also one that affects the lack of human resources.

This is related to the low quality of human resources (HR) and limited budget resources, the community and the tourism office, which occurs in related agencies, resulting in many potential resources (SDA) that have not been optimally utilized, such as the tourism industry, especially Sum-Sum Island, Dodolah Island, Tanjung Gorango, Ngele-Ngele Island, Batu Kopi, Raja Waterfall, Nakamura Waterfall, LeoLeo Waterfall, being accused of occupying a position that is incompatible with one's abilities is also one or the culprit is ineffective and inefficient in implementing policies, affecting underdevelopment of tourism.

The cause of one of the factors of internal constraints is human resources (HR) which is the main obstacle that comes from the internal tourism agency. The existing human resources still understand a little about the implementation of policy No. 09/2014 The Master Plan for Tourism Development with various programs in the policy, thus hindering existing policies or programs experiencing confusion at any time of program implementation or work by the tourism agency. This is in accordance with the expression by Winarno, (2005: 132) that one of the inhibiting factors for policy implementation is sufficient staff only with a sufficient number of implementations to implement a policy, the implementer must have the necessary skills to carry out the work. I think properly trained personnel will hinder policy implementation [2].

Third: Characteristics of implementing organizations Standard operating procedures (SOP) and fragmentation. Fragmentation is a condition due to pressures from the bureaucratic environment, including the political environment to the constitution. Characteristics of the bureaucratic structure Standard Operating Procedures (SOP) and the distribution of responsibility for the implementation of policies in tourism development related to Policy No. 09/2014 concerning the Regional Tourism Development Master Plan (RIPPDA) is one (umbrella) but does not refer to the Regional Tourism Development Master Plan. (RIPKDA).

Fourth: The weakness communication and coordination between related organizations and implementing activities in the case of Regional Government (Regent), private companies, DPRD, Tourism Office and related departments, Society. Example; lack of communication between the Regent and the DPRD. As well as the Tourism Office, Private Companies, Communities held meetings / meetings with coordination / lobbying with private companies and other agencies for tourism development based on Policy No. 09/2014 concerning the Regional Tourism Development Master Plan (RIPPDA), there will be no sample meetings with private companies, if this happens only the companies owned by the regent himself, apart from the regent's own, are not given the opportunity to invest in tourism development, as well as those who are competent in policy / held meetings with and disseminating the existence of the place for policy makers with private parties, as well as related agencies and the community to complete the tourism planning program.

In order for policy to be implemented effectively, according to Van Horn and Van Mater, what constitutes a standard goal must be understood by the individuals (implementers) who are responsible for achieving the standards and policy objectives, therefore standards and goals must be communicated to the implementers. Communication 
within the framework of delivering information to policy implementers about what is the standard and objective must be consistent and uniform (consistency and uniformity) from various sources of information. If there is no clarity and consistency and uniformity of a standard and policy objectives, it is difficult to achieve it. Thus, the prospect of effective policy implementation is largely determined by the communication to policy implementers accurately and consistently. The better communication and coordination between the parties involved in policy implementation, the smaller errors will be and vice versa (in) the Journal of Social Humanities (2015: 97) [5].

There is an authority that guarantees local governments that programs can be directed towards what is expected, at least their special abilities must master communication. Communication between related organizations and implementation activities There is clarity and consistency as well as uniformity of a standard and policy objectives. Policy implementers can know what is expected of them and know what to do. The success of policy implementation is determined by accurate and consistent communication (accuracy and consistency) to policy implementers, as well as coordination between the parties involved in policy implementation.

Fifth: The attitude of policy makers is "from the top down" (top bottomer) and the choice of policy implementation that is self-interested is not based on RIPPDA so that policy implementers who do not know are even unable to touch the needs, wants, or problems that must be resolved. So that in turn the implementation of policies can reduce ineffectiveness and efficiency. Recipient versus rejection; depends on the influence of the policy on the interests of public policy on personal and organizational interests.

The attitude of the central government is serious enough, in terms of tourism development, this is evidenced by the implementation of the sail morotai by Mr. President in 2010, the wornderful event, as well as the central government proclaiming Morotai Island as a national tourism tenure (small bali tourism), in terms of tourism development and In the future, Morotai Island Regency is used as a special economic zone (KEK). The attitude of the implementers should agree with the parts of the policy, so they will carry out happily, but if their views differ from policy makers, the implementation process will experience many problems, this means that the government regions have not shown a serious attitude towards central government policies in tourism development, in terms of budgeting in the APBD.

The attitude in this case the local government and implementors are not in favor of tourism development in terms of budget, the lack of available budget provided by the local government. According to the Head of Marketing, tourism revenue in a year is only IDR. 40,000,000, - while the need to budget, especially for maintenance, is approximately IDR. 500,000,000, - per year, according to the 2015-2016 Regional Budget which is released by the Regional Asset Financial Revenue Service, there is no cost for tourism development if there is no clerical nomen for tourism development, there is no cost for tourism development, budget constraints, statement of the head of the promotion section explained the budget from the central government APBN APBD from 2019-2020 disbursed a very large budget, but with the large budget it was not based on policy (RIPPDA) so that the program implemented was not effective and efficient.

Sixth: Weak support for the social, economic and political environment. The external environment for public policy programs and activities and their operation should be monitored and evaluated regularly so that adjustments or improvements that are needed early can be made. The lack of political support is that it requires direct policy intervention from the Morotai Island Regency DPRD. Empirically, the implementation of local government programs at this time can be found that there are several management programs that are not in accordance with policy Number 09 of 2014 concerning Regional Tourism Development Master Plans (RIPPDA) carried out by local governments (Regent, Tourism Office) and the program is a one-time and type of tourism facilitation. efforts must be made not to exceed the limits of acceptable use. physical support capacity, inadequate tourism facilities and infrastructure found in tourist attractions, security facilities, shopping centers and candramata stores Restaurants for tourists who come to tourism areas visitors are not comfortable for traveling, in terms of community service to tourists who come, such as the lack of community participation in tourism development.

Objective: There is a physical, social and cultural support capacity in tourism development that must be considered and made the main consideration in developing various tourism facilities and activities including physical, social and cultural carrying capacity in harmony with the limits of local capacity and existing environmental support capacities. An example of development in a tourist location is not in accordance with the cultural characteristics of the North Maluku people.

Based on the above problems, this research intends to solve the policy problems of the Morotai Island Regency Government and the Tourism Office. Synergize with Regional Tourism Development Master Plan policies in tourism development. This, the authors conducted a more indepth study, the aim of which is to know more clearly the implementation of policies aimed at the four problems above, and also to what extent the implementation of policies in the implementation of tourism affairs encourages the development of effective and efficient tourism in Morotai Island Regency.

\subsection{Model of Policy Implementation in Tourism Development}

A model is a framework which is an attempt to facilitate the explanation of a social phenomenon which must be explained with an abstract concept. That is, phenomena to fulfill the interests of the public and as far as possible strive to be on the policy rail with the greatest public interest. Van Meter and Van Horn offer a basic model introduced by the duet of Donald Van Meter with Card Van Hord (1975) in 
Riant Nogroho, (2017: 737) this model assumes that policy implementation runs linearly from public policy, implementor, and policy performance [9]. in tourism development policies that affect the performance of policy implementation, six variables that form a bond between policy and achievement:

Implementation and communication activities between organizations,

Characteristics of the implementation agency or implementor,

Economic, social and political conditions, and the disposition of the implementer or implementor

This policy implementation model is built from the results of research in the field, how tourism development programs in the view of public administration can be an alternative in realizing the aims and objectives of policy implementation, local government in this case realizes the vision and mission of areas that develop human resources, the following picture:

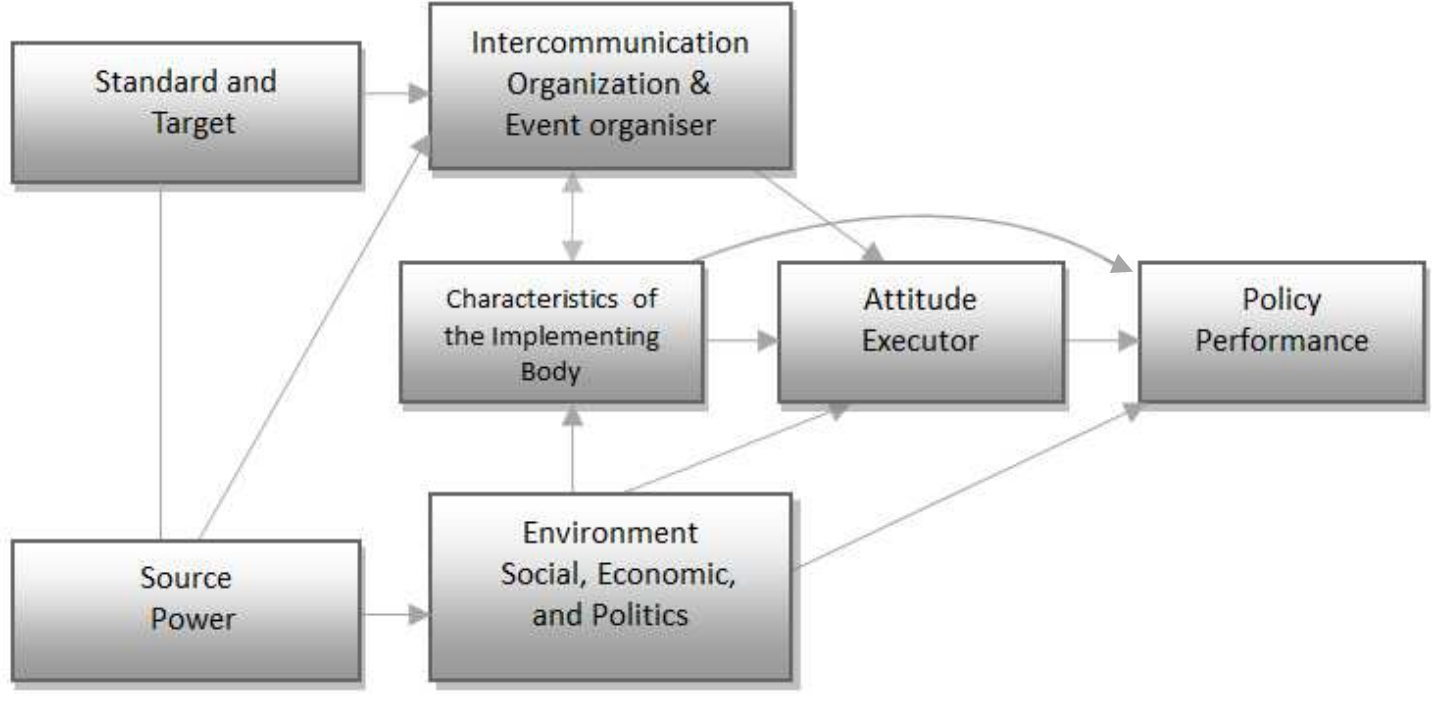

Source: Donald Van Meter and Carl Van Horn: (1975).

Figure 1. Image of Donald Van Meter and Carl Van Horn Models.

\section{Conclusion}

Based on the formulation of the problem put forward, it can be concluded that: The Morotai Island Regency Government has compiled and implemented a Tourism Development Master Plan (RIPPDA) policy as an effort to develop tourism, but the current RIPPDA has not been able to encourage the implementation of regional tourism development. There are various obstacles related to implementing regional government authority that result in the achievement of insignificant policy targets:

1) The implementation of policy No. 09/2014 concerning the Tourism Development Master Plan (RIPPDA), needs to be revised because the policy is general in nature, needs to be supported through specific policies that regulate technical or operational matters related to the development of regional tourism development. However, until now this policy has not been made by the relevant agencies, so there has been no handling of the potential existence of tourism resources in Morotai Island Regency.

2) The factors that influence policy Number 09 of 2014 concerning Regional Tourism Development Master Plans (RIPPDA), namely; 1) Standards, targets, and content of policies for implementation (officials) do not yet understand because there is no socialization for policy interests, in this case policy implementers, so they do not know how the policy standards are in the effectiveness of policy implementation; 2) Human resources, unavailability of: 3) Characteristics of the implementation organization in the form of fragmentation due to not referring to the Regional Tourism Development Master Plan (RIPKDA); 4) The lack of support from the social, economic and political environment.

3) The formulation of policy implementation can be reviewed, namely: 1) The policy implementation process can be seen from the contents of the Regional Tourism Development Master Plan (RIPPDA) policy; 2) Impact of the implementation of the Regional Tourism Development Master Plan (RIPPDA) policy; 3) Strategies and factors influencing the implementation of the Regional Tourism Development Master Plan (RIPPDA) policy, on how the policy is planning to achieve goals in a comprehensive manner.

\section{Suggestion}

1) The local government should be more intense in communicating and collaborating with related agencies in this case, the legislature, NGOs, and academics to be able to evaluate and oversee policy number 09 of 2014 concerning the Regional Tourism Development Master Plan (RIPPDA) to implement the program. 
2) The government, in this case the Tourism Office, should cooperate with the tourism object management association, as well as the community so that the targets set out in the vision and mission can be achieved.

3) The government should need to minimize the factors that hinder or become an obstacle for implementing policies through quality improvement with the suitability of tourism products, and increasing the number and quality of human resources managing tourism and fostering the socio-cultural sector of the community around tourism objects and internal Morotai Island Regency Government.

\section{References}

[1] Agustina Pallewa. (2017). Policy Implication Minimum service standards. Untag's Dissertation.

[2] Budi Winarno, 2017. Public Policy: Revised Edition Theory and Process. Indonesian Public Administration Reform Foundation (YPAPI) \& Lukman Offset, Media Presindo, Yokyakarta.

[3] Bambang Sunaryo. (2013). Tourism Destination Development Policy. Concept and Application in Indonesia. GAVA MEDIA, Yogyakarta.
[4] Burhan Bungin. (2015). Tourism Communication. Tourism Communication, Marketing and Brand Destinations. PREDANAMEDIA GROUP.

[5] Journal of Social Humanities, 2015. ISSN 2087-4928 Volume 6 Number 2, October 2015.

[6] Meleong, Lexy J. 2005. Qualitative Research Methods Bandung: Rosda.

[7] Nawawi Ismail. 2009. Public Policy. Analysis, Advocacy Strategy Theory and Practice, PMN. Surabaya.

[8] Pasolong Harbani. 2011. Public Administration Theory. Alfabeta. Bandung.

[9] Riant Nugroho. (2017). Public Policy. Public policy dynamics, Public policy analysis, Public policy political management, Public policy ethics, Public policy chemistry. Elex Media Komputindo. GRAMEDIA COMPASS.

[10] Rasyid, Ryaas, 2002. Regional Autonomy: Background and Its Front Mass in Syamsudi Haris (ed), Decentralization, Democracy, and Accountability, Jakarta: AIPI and Partnership.

[11] RIPPDA-JM, 2014 in Implementing the Integrated Human Settlements Sector Program Policy, Maluku Utra Province.

[12] Swarbrooke. J. (2003) Sustainable Torism Management London Methuen. 